\title{
Effect of barley grinding method and sodium polyacrylate supplement in the diet on the performance and stomach ulcer development of growing finishing pigs
}

\author{
Timo Alaviuhrola, Marja Hautala, Kaija SuOmi and \\ JUHANI VUORENMAA
}

\begin{abstract}
Alaviuhkola, t., Hautala, M., Suomi, K. \& Vuorenmaa, J. 1993. Effect of barley grinding method and sodium polyacrylate supplement in the diet on the performance and stomach ulcer development of growing finishing pigs. Agric. Sci. Finl. 2: 481-487. (Agric. Res. Centre of Finland, Swine Res. Sta., FIN-05840 Hyvinkää, Finland, National Veterinary and Food Research Institute, Seinäjoki Regional Lab., FIN60101 Seinäjoki, Finland and Cultor Ltd., FIN00240 Helsinki, Finland.)

Two different grinding methods - rolling and hammer milling - as well as polyacrylate supplement in the diet were studied to evaluate their effect on the performance of pigs and the incidence of gastric lesions. The experiment was carried out in $2 \times 2$ factorial arrangement with a total of 160 pigs. The grist size of rolled barley was bigger than of hammermilled barley, but the difference in water-binding capacity was insignificant.

No significant differences were observed in the performance traits of pigs fed either rolled or hammer-milled barley. The sodium polyacrylate supplement had no effect on the daily gain, feed:gain ratio or carcass quality of the pigs. Gastric ulcers and constrictions of the oesophageal opening of the stomach were more frequent in the groups fed hammer-milled barley than in the groups fed rolled barley, the difference being statistically significant $(\mathrm{P}<0.001)$. Sodium polyacrylate supplementation had no protecting effect against the incidence of gastric ulceration in growing finishing pigs.
\end{abstract}

Key words: grinding, gastric ulcer, sodium polyacrylate, pig

\section{Introduction}

Ulcers, erosive lesions and scars are relatively common findings in the stomachs of slaughtered pigs. Prevalence of gastric lesions in slaughter pigs has been reported to be $36 \%$ (HESSING et al. 1992), $5-100 \%$ (O'BRIEN 1986) or 2-50\% (TAYLOR 1986).

Unthriftiness and even sudden death caused by a bleeding gastric ulcer is a well-known disease in sows but is also found in fattening pigs. Gastric ulcers or their preliminary changes are mostly located in the pars oesophagica of the stomach (CURTIN et al. 1963, O'BRIEN 1968). This kerati- nized area of gastric mucous membrane is located around the opening of the oesophagus, and is approximately $8 \mathrm{~cm}$ long and $10 \mathrm{~cm}$ wide (Figs. 1 and 2.). There are no mucus secreting glands in this area. Thus it is quite liable to the acidity of gastric juices. The other part of the stomach (pars glandularis) secretes gastric juices and mucus, the latter being an important protector of the mucous membrane. In this area gastric lesions are relatively uncommon in pigs.

Gastric lesions are mostly limited to the mucosal surface of the stomach, and are not found to cause clinical symptoms or pain. Further, there is no evid- 


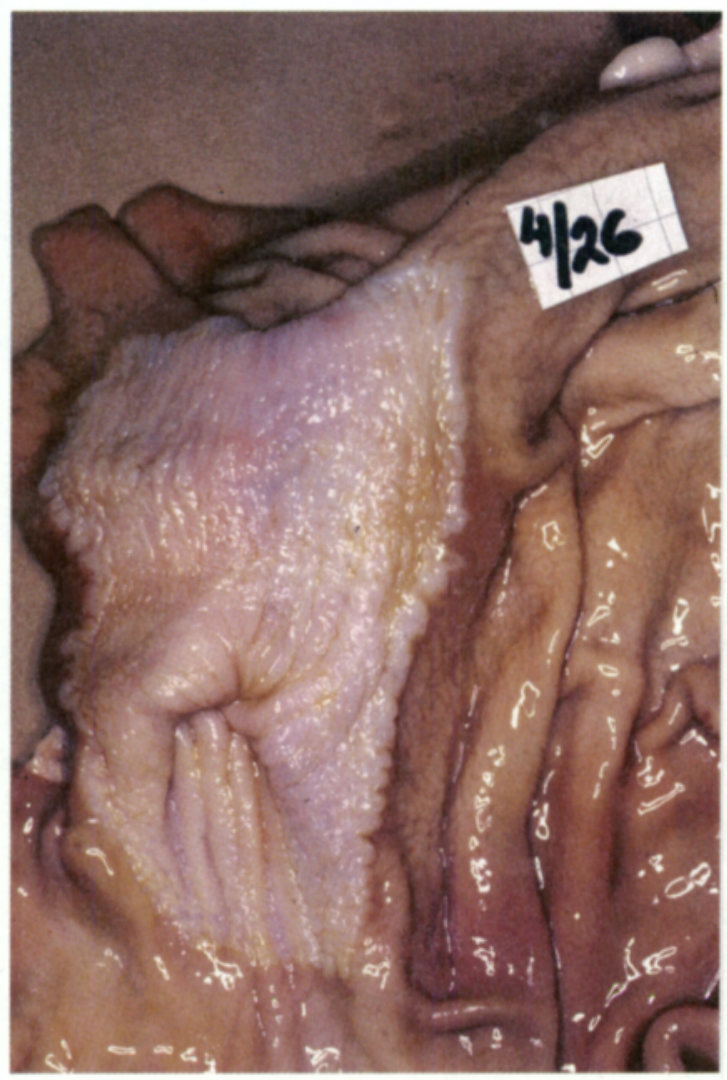

Fig. 1. Normal oesophageal region (pars oesophagica) in the stomach of the pig. (Photo: M. Hautala)

ence of their negative effect on daily weight gain (EHRENSBERGER et al. 1976, BLACKSHAW and KELLY 1980), but they can still develop into fatally bleeding gastric ulcers (Fig. 3). In good circumstances, an ulcer can be healed by scarring. The process of scar-formation may constrict the opening of the oesophagus, which may lead to slower eating, regurgitation and decreased weight gain, or even death (BLACKSHAW and KELLY 1980, NIELSEN 1990).

First-grade gastric lesions are mild, superficial lesions. Second- and third-grade gastric lesions are the real ulcers, thus called severe lesions. The constrictions of the oesophageal opening of the stomach are observed beside epithelial findings, and are always regarded as severe lesions (HAUTALA and RAUTIAINEN 1991).A minor proportion of the mild preliminary changes can be observed only his-

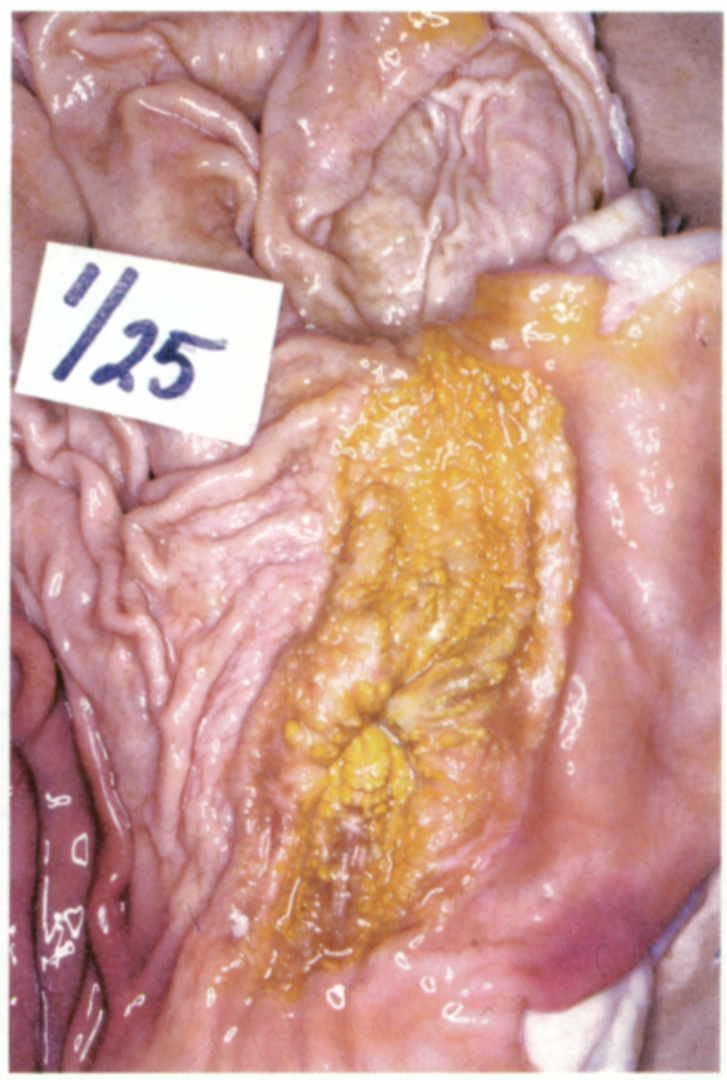

Fig. 2. $1^{\text {st }}$ grade lesion in the oesophageal region (pars oesophagica) of the stomach. (Photo: M. Hautala)

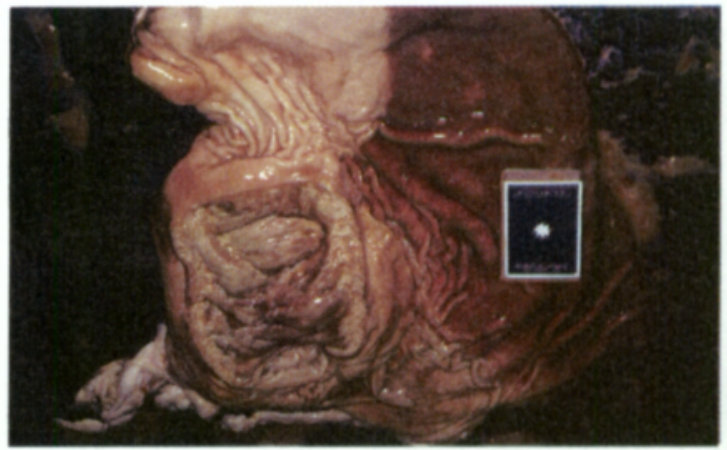

Fig. 3. $3^{\text {rd }}$ grade severe gastric lesion, a crater-like gastric ulcer in the oesophageal region of the stomach. An internal hemorrhage has caused sudden death. (Photo: M. Hautala)

tologically by light microscope (EMBAYE et al. 1990, HAUTALA and RAUTIAINEN 1991). 
Grist size has been reported to be one of the most important risk factors when reasons for gastric lesions have been studied (SIMONSSON 1977). Hammer milling is the most common grinding method in the Finnish feed industry as well on the farms. It is well known that the smaller the particle size when grinding is done with a hammer mill the better the availability of cereal nutrients (ALAVIUHKOLA 1971). No negative relationship between nutrient digestibility and ulceration in pigs was found when roller milling was used (SIMONSSON 1977).

Proper milling and pelleting methods are important in the prevention of gastric lesions. There are some reports about chemical feed supplements which may have beneficial effects. TAMAS et al. (1983) succeeded in preventing oesogastric ulcers in pigs by using vitamin $U$ (S-methyl-methionine sulfonium salt) in the diet. YAmAGUCHI et al. (1981) used sodium polyacrylate (SPA) 0.1 and $0.5 \%$ in the feed of growing pigs and found that this supplementation not only decreased ulceration but also had a beneficial effect on pig performance.

The purpose of the present experiment was to examine the effect of both the milling method and SPA supplementation on the performance of growing finishing pigs and the development of gastric ulcers.

\section{Material and methods}

\section{Animals and examination of stomachs}

A total of 160 piglets were divided into four groups in a $2 \times 2$ factorial experiment. The initial weight of the animals was around $25 \mathrm{~kg}$. They were of Finnish Landrace and Large White origin and came from the sow unit of the Swine Research Station. The piglets were penned four animals in each pen, two females and two castrated males. Litter origin was also used as a balancing factor. The pens were furnished with concrete floor $(170 \times 150 \mathrm{~cm})$ and dunging passage $(170 \times 100)$ with slats. There was $40 \mathrm{~cm}$ trough length for each pig. A small amount of wood shaving was used as the drying material. The animals were weighed fortnightly and sent to slaughter at a weight of $100 \mathrm{~kg}$.
At slaughter the stomachs of the pigs were collected individually. They were opened along the curvatura major of the stomach, emptied, rinsed and chilled close to $0^{\circ} \mathrm{C}$ temperature. They were delivered for laboratory examination within 24 hours. Each stomach was categorizated according to the method of HaUtala and RAUTIAINEN (1991).

Also stomachs with no visible pathological changes were examined histologically. Tissue samples from the margin of pars oesophagica were fixed, dehydrated and embedded in paraffin. The tissue slices were stained with $\mathrm{H}$ \& $\mathrm{E}$ (hematoxylineosin) and examined with 40x and 100x magnifications. After chilling the slaughter quality of all pigs was determined.

\section{Feeds and feeding}

Two grinding methods were used in the preparation of the experimental feeds: hammer milling with a peripherally fed mill, $1500 \mathrm{rpm}$ to pass a $3.5 \mathrm{~mm}$ sieve, and roll milling. The grist size of the two meals was measured with a test sieve shaker for 5 minutes. The water binding-capacity of both meals was measured by mixing 10 grams of water and two grams of sample. The mixture was kept in room temperature for one hour. The free water was then separated in a centrifuge $(5 \mathrm{~min} /$ $3700 \mathrm{rpm}$ ). The water-binding capacity was calculated as the amount of absorbed water $(\mathrm{g}) / \mathrm{sample}$ weight $(\mathrm{g})$.

Two diets were prepared for the whole experimental period by mixing the barley $(77 \%)$ with protein feeds (soybean meal $12 \%$, meat and bone meal $3 \%$ ), vitamins and minerals according to the Finnish recommendations (SALO et al. 1990).

Half of both feeds was supplemented with $0.2 \%$ SPA. The arrangement of the experiment was as follows:

$\begin{array}{lcccc}\text { group } & 1 & 2 & 3 & 4 \\ \text { hammer-milled barley } & + & + & - & - \\ \text { rolled barley } & - & - & + & + \\ \text { Na-polyacrylate, } 0.2 \% & - & + & - & +\end{array}$


Finally the feeds were pelleted, and the content of crude protein and amino acids in the feeds was analyzed.

The pigs were fed twice daily restrictedly. The same amount of feed was used in all treatments, and increased weekly from $1.2 \mathrm{~kg} / \mathrm{pig} / \mathrm{day}$ in the beginning up to the maximum $(3 \mathrm{~kg})$, which was reached in 10 weeks. Dry feed was moistened in the trough before feeding. Water was available all the time.

The data were subjected to an analysis of variance (SNEDECOR and COCHRAN 1967), using the following model:

$$
\begin{aligned}
& \mathrm{Y}_{\mathrm{ijk}}=\mu+\mathrm{a}_{\mathrm{i}}+\mathrm{b}_{\mathrm{j}}+(\mathrm{ab})_{\mathrm{ij}}+\mathrm{e}_{\mathrm{ijk}} \\
& \mathrm{Y} \quad=\text { each individual observation } \\
& \mu \quad=\text { overall mean } \\
& \mathrm{a} \quad=\text { effect of grinding method }(\mathrm{a}=1,2) \\
& \mathrm{b} \quad=\text { effect of SPA supplement }(\mathrm{b}=1,2) \\
& (\mathrm{ab})_{\mathrm{ij}}=\text { grinding } \mathrm{x} \text { SPA interaction } \\
& \mathrm{e}_{\mathrm{ijk}} \quad=\text { residual term }
\end{aligned}
$$

The result of a single pig was used as an observation except in the calculation of feed:gain ratio, where the result of pen was used. The Kruskal-Wallis method was applied to test the frequency of gastric lesions in the stomachs. The relationship between the incidence of gastric lesions and daily weight gain of pigs was tested by the Spearman correlation test (SNEDECOR and COCHRAN 1967).

\section{Results and discussion}

Two pigs were lost from group 3. The reasons were inborn heart defect in the first case and umbilical hernia in the other. One pig was removed from group 4 due to slow growth. One stomach was lost in the rinsing process at the slaughterhouse.

The crude protein and amino acid content in the four mixtures was almost the same as expected. In the three samples taken from the barley meal, the water-binding capacity was higher in rolled than in hammer milled barley ( 2.2 vs 1.9$)$. This indicates that the total surface area of the meal particles was probably bigger in rolled than in hammer milled barley. The grist spectrum of the two meals is shown in Table 1.
Table 1. Particle size distribution of rolled and hammer-milled barley.

\begin{tabular}{lccc}
\hline Particle diameter, mm & $\begin{array}{c}\text { Rolled } \\
\text { barley }\end{array}$ & $\begin{array}{c}\text { Hammer- } \\
\text { milled barley }\end{array}$ \\
\hline $4.0>$ & $\%$ & 2 & 0 \\
$2.5-4.0$ & $\%$ & 21 & 0 \\
$1.6-2.5$ & $\%$ & 35 & 2 \\
$1.0-1.6$ & $\%$ & 26 & 22 \\
$0.3-1.0$ & $\%$ & 14 & 66 \\
$<0.3$ & $\%$ & 2 & 10 \\
\hline
\end{tabular}

There were no differences in the performance between pigs fed hammer milled or rolled barley. This agrees with the results reported by SIMONSSON (1977). It may be concluded that grist size is not the best indicator of the nutrient availability of ground meal. The total surface area of the particles seems to be more important. Digestibility trials done by NÄSI (1992) with barley handled with same grinding methods as in the present experiment, showed the same digestibility for crude protein and nitrogen-free extract.

No significant differences in the carcass quality of pigs between the treatments were found. The performance and carcass quality of the pigs is shown in Table 2.

SPA supplementation had no effect either on the daily gain or the feed:gain ratio of the pigs. Neither was there any grinding method $x$ SPA interaction. In their studies on the mode of action of SPA, KOKUE et al. (1983) and YAMAGUCHI et al. (1981) found that SPA had an antipeptic activity and caused a reduction of the free-acid content of gastric juice in rat trials. In pigs, a prolonged retention of the diet in the stomach was noticed. In the present experiment, SPA was not observed to have any effect on the performance of pigs.

The observed gastric lesions are presented in Table 3. The expression "severe lesions" denotes the sum of second and third grade lesions and the oesophageal constrictions. All the lesions, except one, were located in the pars oesophagica. In the stomach of one pig fed hammer-milled barley without SPA supplement, the second-grade ulcer was found in pars glandularis. All the first-grade lesions 
Table 2. Effect of two different grinding methods and sodium polyacrylate (SPA) supplement on daily gain, feed consumption and carcass quality of growing pings.

\begin{tabular}{|c|c|c|c|c|c|c|c|c|c|c|c|}
\hline \multirow{5}{*}{$\begin{array}{l}\text { Group } \\
\text { Milling1) } \\
\text { SPA. } 0.2 \% \\
\text { Number of pigs }\end{array}$} & \multirow{2}{*}{\multicolumn{2}{|c|}{$\begin{array}{c}1 \\
\mathrm{HM}\end{array}$}} & \multirow{2}{*}{\multicolumn{2}{|c|}{$\begin{array}{c}2 \\
\mathrm{HM}\end{array}$}} & \multirow{2}{*}{\multicolumn{2}{|c|}{$\begin{array}{c}3 \\
\mathrm{RM}\end{array}$}} & \multirow{2}{*}{\multicolumn{2}{|c|}{$\begin{array}{c}4 \\
\mathrm{RM}\end{array}$}} & \multicolumn{3}{|c|}{ Significance } \\
\hline & & & & & & & & & \multirow{4}{*}{ Milling } & \multirow[t]{4}{*}{ SPA } & \multirow{4}{*}{$\begin{array}{l}\text { Milling } \\
\text { *SPA }\end{array}$} \\
\hline & \multirow{2}{*}{\multicolumn{2}{|c|}{$\overline{40}$}} & \multirow{2}{*}{\multicolumn{2}{|c|}{$\begin{array}{c}+ \\
40\end{array}$}} & \multirow{2}{*}{\multicolumn{2}{|c|}{40}} & \multirow{2}{*}{\multicolumn{2}{|c|}{$\begin{array}{l}+ \\
40\end{array}$}} & & & \\
\hline & & & & & & & & & & & \\
\hline & mean & $\mathbf{s}$ & mean & s & mean & s & mean & s & & & \\
\hline Initial weight & 25.2 & 1.19 & 25.2 & 1.23 & 25.2 & 1.23 & 25.1 & 1.01 & NS & NS & NS \\
\hline $\begin{array}{l}\text { Final weight } \\
\text { (corr. to } 25 \% \text { loss) }\end{array}$ & 101.0 & 3.70 & 101.6 & 3.09 & 100.9 & 3.08 & 101.7 & 2.79 & NS & NS & NS \\
\hline Days in trial & 85.7 & 6.95 & 86.0 & 6.76 & 84.6 & 6.61 & 85.4 & 7.71 & NS & NS & NS \\
\hline Daily gain, g & 889 & 66.53 & 893 & 58.65 & 899 & 64.30 & 903 & 65.27 & NS & NS & NS \\
\hline Feed: gain ratio & 2.28 & 0.09 & 2.29 & 0.07 & 2.26 & 0.06 & 2.29 & 0.07 & NS & NS & NS \\
\hline Side fat, mm & 16.9 & 4.51 & 17.5 & 4.95 & 18.0 & 3.99 & 17.8 & 4.76 & NS & NS & NS \\
\hline Lean colour ${ }^{2)}$ degr. & 37.7 & 2.76 & 38.2 & 3.89 & 37.9 & 2.55 & 37.9 & 4.19 & NS & NS & NS \\
\hline $\begin{array}{l}\text { Per cent lean }+ \text { bone } \\
\text { in carcass }\end{array}$ & 54.0 & 2.52 & 53.9 & 2.27 & 53.9 & 1.49 & 53.5 & 2.68 & NS & NS & NS \\
\hline
\end{tabular}

1) $\mathrm{HM}=$ hammer-milled, $\mathrm{RM}=$ roller-milled

2) EEL smoke reflectometer

Table 3. Effect of grinding method and sodium polyacrylate (SPA) supplement on the incidence of gastric lesions in pigs.

\begin{tabular}{|c|c|c|c|c|c|c|c|}
\hline & \multirow{2}{*}{$\begin{array}{l}\text { Number } \\
\text { of pigs }\end{array}$} & \multicolumn{4}{|c|}{ Grades of gastric lesion } & \multirow{2}{*}{$\begin{array}{l}\text { Number of stomachs } \\
\text { with constriction of } \\
\text { oesophageal opening }\end{array}$} & \multirow[t]{2}{*}{ Severel) lesions, tot. } \\
\hline & & 0 & 1 & 2 & 3 & & \\
\hline Hammer-milled & $\begin{array}{l}80 \\
\%\end{array}$ & $\begin{array}{l}1 \\
1.25\end{array}$ & $\begin{array}{l}66 \\
82.50\end{array}$ & $\begin{array}{l}13 \\
16.25\end{array}$ & $\begin{array}{l}0 \\
0\end{array}$ & $\begin{array}{l}5 \\
6.25\end{array}$ & $\begin{array}{l}15 \\
18.75\end{array}$ \\
\hline Rolled & $\begin{array}{l}76 \\
\%\end{array}$ & $\begin{array}{l}29 \\
38.16\end{array}$ & $\begin{array}{l}47 \\
61.84\end{array}$ & $\begin{array}{l}0 \\
0\end{array}$ & $\begin{array}{l}0 \\
0\end{array}$ & $\begin{array}{l}1 \\
1.25\end{array}$ & $\begin{array}{l}1 \\
1.25\end{array}$ \\
\hline SPA & $\begin{array}{l}78 \\
\%\end{array}$ & $\begin{array}{l}17 \\
21.79\end{array}$ & $\begin{array}{l}54 \\
69.23\end{array}$ & $\begin{array}{l}7 \\
8.97\end{array}$ & $\begin{array}{l}0 \\
0\end{array}$ & $\begin{array}{l}3 \\
3.85\end{array}$ & $\begin{array}{c}8 \\
10.26\end{array}$ \\
\hline SPA $0,2 \%$ & $\begin{array}{l}78 \\
\%\end{array}$ & $\begin{array}{l}13 \\
16.67\end{array}$ & $\begin{array}{l}59 \\
75.64\end{array}$ & $\begin{array}{l}6 \\
7.69\end{array}$ & $\begin{array}{l}0 \\
0\end{array}$ & $\begin{array}{l}3 \\
3.85\end{array}$ & $\begin{array}{c}8 \\
10.26\end{array}$ \\
\hline
\end{tabular}

1) Sum of 2 nd and 3rd grade ulcers and constrictions.

in stomachs of pigs fed hammer-milled barley could be observed macroscopically. Of the 47 firstgrade lesions found in the stomachs of pigs fed rolled barley, 25 were detectable only microscopically. Second-grade gastric lesions were found only in pigs fed hammer-milled barley. No third-grade ulcers were observed in this material.

The number of severe gastric lesions was higher in the stomachs of pigs fed hammer-milled barley than those fed rolled barley. The difference was statistically significant $(\mathrm{P}<0.001)$. On the other hand, SPA supplement in the feed seemed to have no effect on the incidence of gastric lesions.

The result is in accordance with the findings reported by SIMONSSON (1977) and MAHAN et al. (1966), who also compared different grinding methods. However, there is a contradiction between this result and the results of YAMAGUCHI et 
al. (1981), which may be partly explained by differences in further processing (pelleting) of the experimental feeds.

The incidence of severe gastric lesions did not seem to affect the daily gain of pigs $(r=0.02)$. Earlier reports (BLACKSHAW and KELLY 1980, NIELSEN 1990) have come to the same conclusion.
However, the frequency of severe gastric lesions in pigs fed hammer milled barley was $16 \%$ in present experiment. The question may be raised whether it is acceptable from the ethical point of view that pigs have pathological, maybe painful lesions, even though they do not affect performance.

\section{References}

Alaviuhrola, T. 1971. Sioille kảytettävän rehujauhon edullisin hienousaste. Sika 3: 20-21.

Blackshaw, J. K. \& Kelly, W. R. 1980. Effects of gastric ulceration on growth rate of intensively reared pigs. Vet. Rec. 106: 52-54.

Curtin, T. M., Goetsch, G. D. \& Hollandbeck, R. 1963. Clinical and pathologic characterization of oesophagogastric ulcers in swine. JAWMA 143: 854-860.

Ehrensberger, F., Jucker, H., Pfirter, H.P., Pohlenz, J. \& SCHLATtER, CH. 1976. Einfluss der Futterbeschaffenheit auf das Auftreten oesophagogastrischer Geshwure und auf die Mastleistung beim Schwein. Zbl. Vet. Med. Reihe A, 23: 265276.

Embaye, H., Thomlinson, J. R. \& Lawrence, T. L. J. 1990. Histopathology of oesophagogastric lesions lesions in pigs. J. Comp. Path. 103: 253-264.

Hautala, M. \& Rautiainen, E. 1991. A comparative study of feeder pig units using dry or liquid feeding in the western part of Finland. Part 2: Assessment and categorisation of the gastric lesions in pigs. Suomen eläinlääkärilehti 97: 298-307.

Hessing, M. J. C., Geudeke, M. J., Scheepens, C. J. M., Tielen, M. J. M., Schouten, W. G. D. \& Wiepkema, P. R.1992. Mucosal lesions in the pars oesophagea in pigs: prevalence and influence of stress. Tijdschrift voor Diesgeneeskunde 117: 445-450.

Kokue, E., Kurebayashi, Y., Shimoda, M. \& Hayama, T. 1983. Evaluation of prophylactic activity of drugs on swine gastroesophageal ulcer induced by betazole-reserpine using the method of endoscopy. Jpn. J. Vet. Sci. 45, 2: 143-149.

Mahan, D. C., Pickett, R. A., Perry, T. W., Curtis, T. M., FeAtherston, W. R. \& BeEson, W. M. 1966. Influence of various nutritional factors and physical form of feed on esophagogastric ulcers in swine. J. Anim. Sci. 25: 10191023.

NÄSı, M. 1992. Effects of grinding, pelleting and expanding on nutritive value of barley in pig diets. Agric. Sci. Finl. 1: 461-469.

NiElsEn, E.K. 1990. The influence of feeding on the development and health of slaughter pig stomachs and on appetite. 41st Annual Meeting of the European Association for Animal Production.
O'BRIEN, J.J. 1968. Survey of the incidence of gastric ulceration (pars oesophagea) in bacon pigs in Ireland. Vet. Rec. 83: 245248 .

- 1986. Gastric ulcers. In: Leman, A. D. (ed.). Diseases of Swine. Iowa State University Press, Ames. p. 725-737.

SAlo, M.-L., TuORI, M. \& KIISKINEN, T. 1990. Rehutaulukot ja ruokintanormit. Helsinki. 70 p.

Simonsson, A. 1977. Effects of grist size of barley on the performance and the incidence of oesophagogastric lesions in growing pigs. Uppsala. $271 \mathrm{p}$.

SNedecor, G. W. \& Cochran, W.G. 1967. Statistical methods. 7 th ed. 597 p. The Iowa State University Press, Ames, Iowa, USA.

TAmas, J., Hegedus, M. \& BoKORI,J. 1983. Oesophagogastric ulcer in swine and vitamin U. III. Reduction of economic losses by vitamin U. Acta Vet. Hungarica 34 :81-92.

TAYLOR, D J. 1986. (ed.). Pig Diseases. The Burlington Press (Cambridge) Ldt, Foxton. p. 256-261.

Yamaguchi, M., Takemoto, T., Sakamoto, K., Asano, T., UCHIMURA, M. \& MASUdA, I. 1981. Prevention of gastric ulcers in swine by feeding of sodium polyacrylate. Am. J. Vet. Res. 42: 960-962.

\section{Manuscript received April 1993}

Timo Alaviuhkola

Kaija Suomi

Agricultural Research Centre of Finland

Swine Research Station

FIN-05840 Hyvinkää, Finland

Marja Hautala

National Veterinary and Food Research Institute

Seinäjoki Regional Laboratory

Box 198

FIN-60101 Seinäjoki, Finland

Juhani Vuorenmaa

Cultor Ltd.

Kyllikinportti 2

FIN-00240 Helsinki, Finland 


\title{
SELOSTUS
}

\section{Viljan jauhatustavan ja natriumpolyakrylaattilisäyksen vaikutus lihasikojen kasvuun, rehun hyväksikäyttöön ja mahahaavauman esiintymiseen}

\author{
Timo Alaviuhkola, Marja Hautala, Kaija SuOmi ja \\ JUHANI VUORENMAA
}

Maatalouden tutkimuskeskus, Eläinlääkintä- ja Elintarvikelaitos ja Cultor Oy

\begin{abstract}
Ohran jauhamistavan ja natriumpolyakrylaattilisåyksen $(0,2 \%)$ vaikutuksia lihasikojen kasvuun, rehun hyväksikäyttöön sekä mahahaavauman esiintymiseen tutkittiin ruokintakokeessa 160 sialla. Koerehut sisälsivät ainoana rehuviljana ohraa $77 \%$. Osa ohrasta jauhettiin vasaramyllyllä, osa valssimyllyllä. Vasaramyllyllä jauhetun viljan hiukkaskoko oli pienempi kuin valssatun ohran. Siitä huolimatta jälkimmäisen vedensidontakyky oli suurempi johtuen luultavasti partikkelien suuremmasta kokonaispinta-alasta.
\end{abstract}

Jauhatusmenetelmällă ei ollut vaikutusta sikojen kasvuun, rehun hyväksikäyttöön eikä teuraslaatuun. Vasaramyllyllä jauhettua viljaa syöneiden sikojen mahalaukkujen esophagusosassa todettiin selvästi enemmän mahahaavauman esiastemuutoksia sekä vakavia mahahaavaumia kuin valssimyllyllä jauhetulla viljalla ruokittujen sikojen mahalaukuissa.

Natriumpolyakrylaattilisäyksellä ei ollut vaikutusta sikojen tuotantotuloksiin. Se ei myöskään kyennyt ehkäisemään mahahaavauman esiasteiden syntymistä. 